\title{
Consumption Rates of Invasive Freshwater Gastropod Pomacea Canaliculata on Aquatic Plants from Shatt Al-Arab River, Basra, Iraq
}

\author{
Anfas N. Ukash ${ }^{1} \quad$ Khaled Kh Al-Khafaji $^{2} \quad$ Rafid M. Karim ${ }^{2}$ \\ 1.Ecology department, College of science \\ 2.Marine Biology Department, Marine Science Centre
}

\begin{abstract}
Pomacea canaliculata (Gastropoda: Ampullariidae) is a common species in many parts of the world and an important consumer of aquatic macrophytes. We conducted laboratory tests to quantify the rates of consumption of aquatic plants in Shatt Al-Arab River, Basra, Iraq. six freshwater plant species were presented to an invasive $P$. canaliculata in laboratory tests.

This study was carried out during January to December 2017 to evaluate the consumption rates to specific aquatic plants than others by freshwater snails Pomacea canaliculata. Specimens of Snails were collected from ponds in intertidal zones at banks of Shatt al-Arab River near Al- Salhyaa canal in Shatt Al- Arab city from aquatic plants; Typha domingensis, Phragmites australis, Bacopa monniera, Ceratophyllum demersum and Potamogeton crispus. The presence of these Specimens aquatic plants was affected by the water temperature and salinity, they almost disappear in winter leading to low snail numbers at that season.

Statistical analysis shows a significant differences $(\mathrm{P}<0.05)$ between numbers of snails on five aquatic plants in the field that were these are collected.

Bacopa monniera, Lemna minor, $C$. demersum and $P$. crispus were the higher preferred to snails in this study, while $T$. domingensis, $P$. australis recorded lower preferred by snails.

In this study we use snail Pomacea canaliculata as a biological control agent of common macrophyte weeds species.

Results indicated that P. canaliculata reared on Lemna, Bacopa, Ceratophyllum and Potamogeton had the highest food preference and consumption rates, but all individuals fed with Phragmites showed lowest feeding consumption rates and little the food preference. significantly differing from the others. However, in the absence of Bacopa , Lemna, Ceratophyllum and Potamogeton were consumed.
\end{abstract}

Keywords: Consumption rate, aquatic plants, Pomacea canaliculata, Snail .

DOI: $10.7176 /$ JAAS/52-07

\section{Introduction}

Snail Pomacea canaliculata originates in the tropical region of South America (Estebenet \& Martín, 2003)[1]. Its diet consists of periphytons, macrophytes, debris and organic matter, and it changes its food preference during the ontogenetic development; it displays preference for detritus and algae when young, and for aquatic macrophytes, as adults (Hirai, 1988). This mollusk's eating habits involve numerous aquatic plants, and its food preference is basically defined by the ratio of availability of nitrogen, dry matter content, presence of defense substances and phenolic compounds of plants (Qui \& Kwong, 2009; Wong et al., 2010; Qui et al., 2011). This snail also eats some crops, such as Colocasia esculenta (Qui \& Kwong, 2009) and Oryze sativa (Halwart, 1994).

The freshwater snail Pomacea canaliculata ranges naturally from temperate South America northwards perhaps as far as the Amazon basin. It is one of several species of the family Ampullariidae commonly called 'apple snails'. Intentional introductions of apple snails as potential food resources have resulted in successful invasions in many regions, particularly southeast Asia (Acosta and Pullin 1991; Naylor 1996).

Aquatic plants become a cause for concern when they form dense settlements, exceeding the environment's carrying capacity for their population and causing negative impacts to the multiple uses of water bodies. At high densities and high occupancy rates of the water body, the submersed plants promote reduction of oxygen available in the water column, especially at night, with reflections on the local biological diversity, negatively affecting fish populations, and hindering fish catch, river transport, water sports and the generation of electricity (Borges Neto \& Pitelli, 2004; Souza, 2011)[9, 10].

Biological control of submerged aquatic plants is well studied using various organisms such as insects (Newman, 2004; Sullivan et al., 2011; Center et al., 2013); fish as Piaractus mesopotamicus (Miyazaki \& Pitelli, 2003) and grass carp Ctenopharyngodon idella (Gettys et al., 2009; Silva et al., 2014); microorganisms (Borges Neto \& Pitelli, 2004); and mollusks (Lach et al., 2000; Wong et al., 2010).

The present study assesses the feeding rates of $\mathrm{P}$. canaliculata on 6 common aquatic macrophytes in intertidal zones at banks of Shatt al-Arab River near Al- Salhyaa canal in Basrah city, Iraq. 


\section{Materials and Methods}

The samples of the snail P. canaliculata and aquatic plants; Typha domingensis, Phragmites australis, Bacopa monniera Lemna minor, Ceratophyllum demersum and Potamogeton crispus. were collected from ponds in intertidal zones at banks of Shatt al-Arab River near Al- Salhyaa canal in Shatt Al- Arab city (figure 1). To estimate snail density we applied "quadrat Count" by used a quadrate $1 / 2 \mathrm{~m}^{2}$ and pulling the plants using a fork like tool.

To monitor changes in snail population at this sites" a simple random sampling was conducted on monthly interval between January to December 2017 three sampling quadrats were randomly placed After that, searching for snails by hands and counting were carried out at low tidal period. These specimens were brought to the laboratory where all animals were kept in aquarium for identifications and study.

snails were classified and counted. The collected snails were measured according to (Estebenet and Martín, 2003). The identification was based on shell morphology (Simone, 2006) and by the features of the egg clutches (Estebenet and Cazzaniga,1993), picture 1.

The physical and chemical parameters that were taken in the field by multi meter yasi including $\mathrm{pH}$, water temperatures, dissolved $\mathrm{O}^{2}$ and salinity.

Different body measurements including shell length, width and aperture length and width were measured as per given measurement details (Figure 2).

The consumption and feeding preference of the snail $P$. canaliculata for Aquatic plants were evaluated by conducting test.

In this test, After collection, snails were held in tap water at room temperature $\left(25 \pm 2{ }^{\circ} \mathrm{C}\right)$ salinity $1.5-2.4$ ppt and starved for a minimum of $24 \mathrm{~h}$ before experimentation. We collected six species of plants for the consumption and food choice experiments: Typha domingensis, Phragmites australis, Bacopa monniera, Lemna minor, Ceratophyllum demersum and Potamogeton crispus,

In the consumption test of aquatic plants were tendered separately. A plastic container with liter of water and 1 an adult snails were used in consumption assays [25-35 $\mathrm{mm}:$ shell length (SL)], then $10 \mathrm{~g}$ of biomass of each aquatic plants were offered. For weighing the plants, the excess water accumulated on the surface was removed with a light pressure with an absorbent paper and the biomass was measured on an analytical balance. The test was conducted for 14 days, and the evaluation of the plants was performed every 24 hours. In each evaluation, the remaining biomass was weighed and discarded. Then, a new amount of 10 grams was offered to the snail for another 24 hours of predation and seven evaluations were held. Each vial was considered an experimental unit, and the containers were arranged in a completely randomized design with four replications.

Aquatic plant consumption was calculated by the biomass reduction percentage relative to the amount offered at the beginning of each period. At the end of the experiment, these data were submitted to analysis of variance and compared by Tukey test at $5 \%$ probability.

\section{Results and Discussion}

The values of the water parameters were differed monthly during 2017 in ponds of the study site, that the sampling were collected (ANOVA, $p>0.05$ ). Dissolved oxygen and $\mathrm{pH}$ ranged from 8.4 to $4.7 \mathrm{mg} / \mathrm{land}$ from 7.76 to 8.27 , respectively, and $\mathrm{pH}$ showed no variation among study months. Salinity differed significantly among study months, with the lowest levels recorded during the winter months and the highest during the summer months $(p<0.05)$. The temperature was significantly lower during the winter months $(15 \circ \mathrm{C})$ than during the summer months $(34 \circ \mathrm{C}) .(p<0.05)$.

Table 1. Some physical and chemical in ponds at intertidal zone in the banks of Shatt Al- Arab river.

\begin{tabular}{|l|l|l|l|l|}
\hline Months & D. oxygen $\mathbf{~ g} / \mathbf{l}$ & pH & Salinity ppt & Temperature ${ }^{\circ}$ C \\
\hline January 2017 & 8.6 & 8.2 & 1.8 & 15 \\
\hline Feb. & 8.5 & 8.4 & 1.9 & 19 \\
\hline Mar. & 8.3 & 8.5 & 2.1 & 21 \\
\hline Apr. & 7.5 & 7.8 & 2.5 & 26 \\
\hline May & 6.4 & 7.6 & 3.5 & 29 \\
\hline Jun. & 5.8 & 8.1 & 4.7 & 33 \\
\hline Jul. & 5.5 & 8.0 & 5.6 & 34 \\
\hline Aug. & 5.2 & 8.4 & 6.5 & 29 \\
\hline Sep. & 6.0 & 7.7 & 6.5 & 27 \\
\hline Oct. & 6.2 & 7.9 & 6.2 & 26 \\
\hline Nov. & 6.8 & 7.6 & 3.7 & 25 \\
\hline Dec. 2017 & 7.8 & 7.8 & 3.1 & 21 \\
\hline
\end{tabular}

Snail density in the sampling area ranged from 10 to 38 individual $\mathrm{m}^{2}$ for all study months (Fig. 2). Highest densities were recorded at all study months in study site, while the lowest densities observed at most of the 
months of winter season from January 2017 to March 2017.

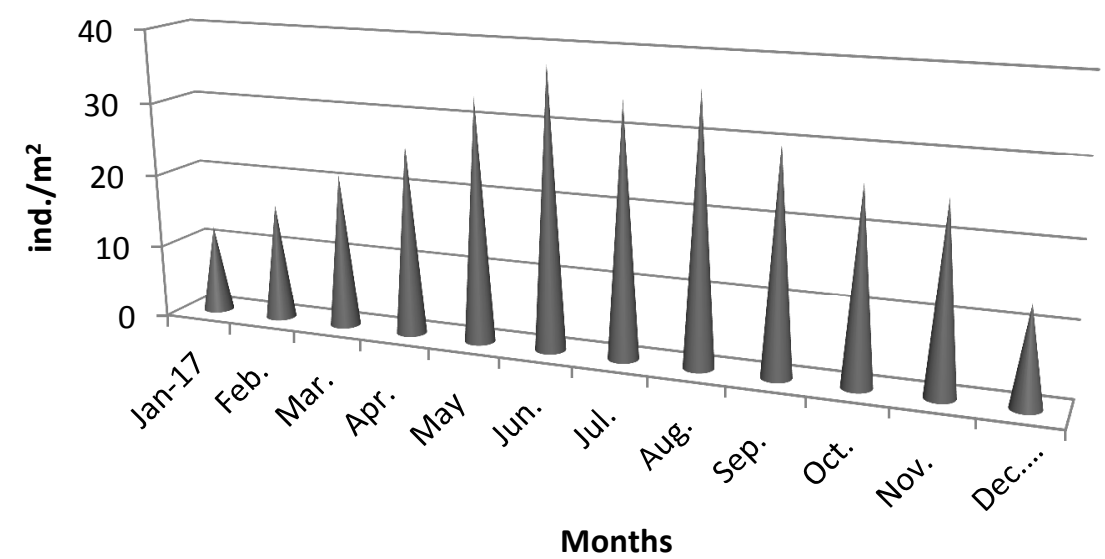

Fig. 2: Population density ( Ind./ $\mathrm{m}^{2}$ ) of P. canaliculata during Jan. to Dec. 2017 in pond in intertidal zone of Shatt Al-Arab river.

Snail P. canaliculata showed a higher consumption of Lemna minor, Bacopa monniera, Ceratophyllum demersum and Potamogeton crispus with an average of $7.42 \pm 3.7 \mathrm{~g} / \mathrm{day}, 5.66 \pm 1.8 \mathrm{~g} / \mathrm{day}, 3.84 \pm 2.12 .86 \pm 3.9$ $\mathrm{g} /$ day respectively, in 24 hours of exposure. This value was significantly higher than the consumption level for other plants. While the consumption of Typha domingensis was of $0.87 \pm 0.96 \mathrm{~g} /$ day, being statistically higher than that observed for the other plant offered: Phragmites australis. The average consumption of Phragmites australis was of $0.19 \pm 0.04 \mathrm{~g} /$ day, in the period of 24 hours; significant differences among these values were detected by the Tukey test at $5 \%$ probability.

The consumptions for P. canaliculata were lower than the ones observed for Lemna minor (5.4 g day-1), according to what was observed by Carlsson \& Lacoursière (2005), and also for C. demersum (6.51 g day-1), performed by snail Pomacea insularium (Baker et al, 2010). These differences are related to the ecological conditions of the experiment in the laboratory and snails sizes used.

In the reduction of the biomass supplied, there was a difference among the six studied macrophytes. The average biomass reduction of $L$. minor was $82.37 \pm 5.18$ and B. monniera was of $75.25 \pm 9.53 \%$, while was 33.53 $\pm 8.24 \%$ for P. crispus, $27.27 \pm 9.94 \%$ for C. demersum (Figure 2). In the two most preyed species there was little variation in the amounts consumed in periods of 24 hours, and the consumption ratio between them was almost the same in the period of the observations. As for the relationship between P. crispus and C. demersum, more profound changes occurred in the trial period. In the first day, the consumption of $C$. demersum was higher than the consumption of $P$. crispus. In the fifth, sixth and seventh day, the relative consumption was reversed, with higher predation of $P$. crispus in relation to $C$. demersum. In the other observations, the quantities consumed by these two species showed small differences.

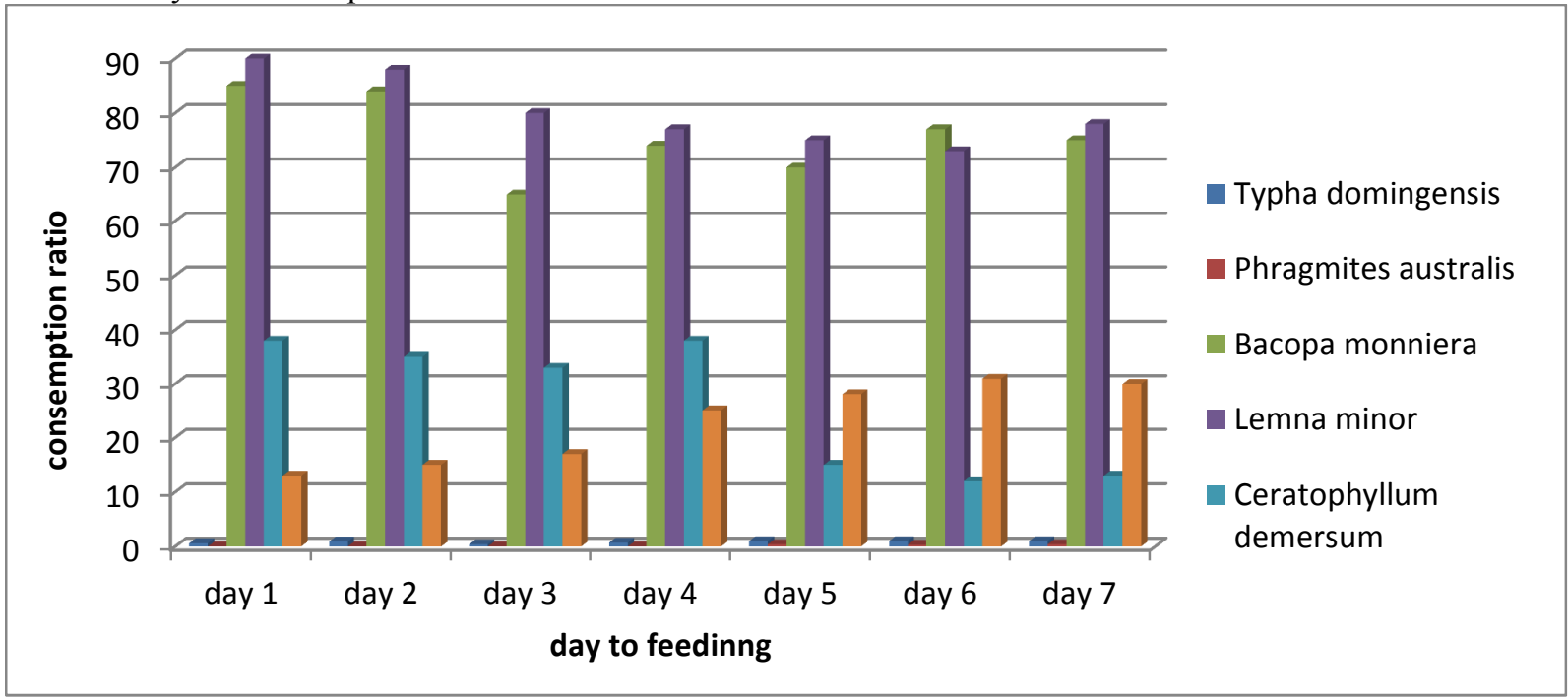

Figure 2 - Percentage of consumption of aquatic macrophytes by snail Pomacea canaliculata in 24 hours experiment in the laboratory at the same time. 
During the assessment period (14 days), the snails fed on L. minor and B. monniera had the greatest increases in body mass, with gain, on average, of $0.65 \mathrm{~g} /$ day and $0.58 \mathrm{~g} /$ day, respectively. Animals fed on $C$. demersum and P. crispus had mass reduction of $0.15 \mathrm{~g}$ and $0.12 \mathrm{~g} /$ day, respectively. Individuals fed P. australis showed a small weight gain: $0.049 \mathrm{~g} /$ day.

$P$. canaliculata is recognized for having great herbivory power and low selectivity (Lach et al., 2000; Carlsson \& Lacoursière, 2005; Carlsson \& Brönmark, 2006). However, their food preference can be a tool in the management of L. minor.

Thus, the results obtained in this study are similar to the ones found by other authors (Estebenet, 1995; Lach et al. 2000; Carlsson \& Lacoursière, 2005; Carlsson \& Brönmark, 2006) and indicate that P. canaliculata actively selects its food and displays a clear preference for certain species of macrophytes.

The results of these experiments allow us to infer that there is a potential for use of this snail in the biological control of L. minor by inundative or repositioning strategies. This latter strategy is used with grass carp, which is a herbivorous fish, but with food preference for some species. The animal load placed is planned to control only the target species (Gettys et al., 2009).

Thus, it is concluded that $P$. canaliculata has potential for use as a biocontrol organism of submerged aquatic macrophyte $L$. minor.

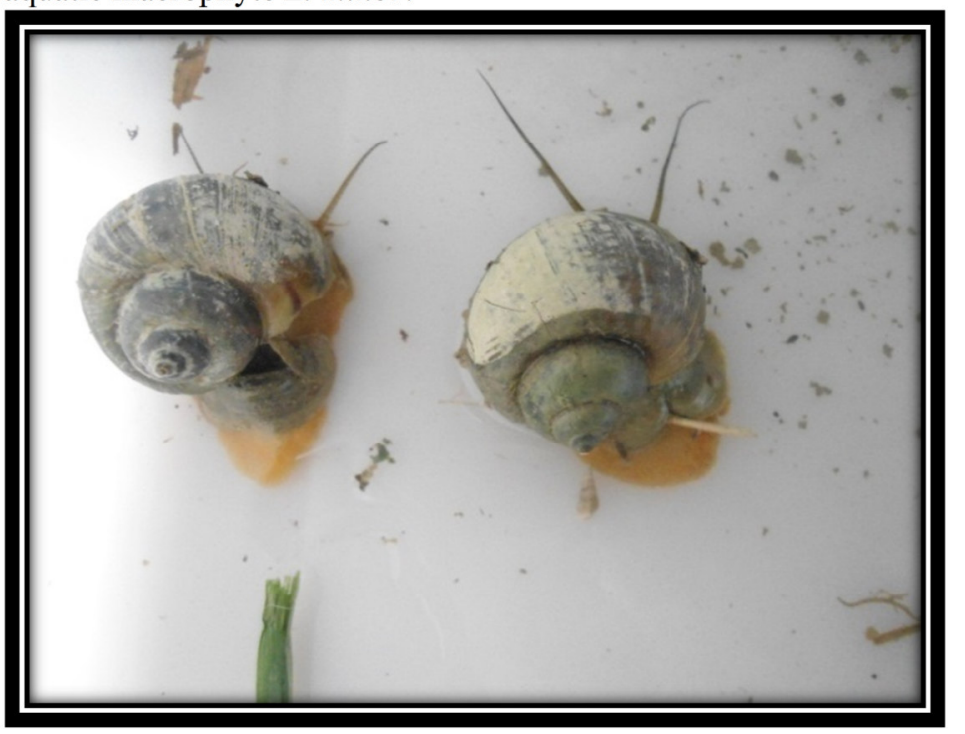

Picture 1. Its image represents the snail during the experiment in the laboratory

\section{Conclusion}

In conclusion, $P$. canaliculata showed a strong feeding response, both in terms of quantity of plants consumed, and in the proportion of the snails that fed. Moreover, there was a wide range in feeding response between plant species, allowing us to make inferences regarding relative preferences. Some useful and harmful plants species were consumed readily, but other harmful species were consumed at a relatively low rate or not at all. The impact of $P$. canaliculata on monocultures of these species will depend, in part, on growing conditions and productivity of the plants. However, our results show that in 'natural' ecosystems, with both useful and harmful plants, $P$. canaliculata cannot be relied upon as an agent for biological control of harmful species and may heavily impact useful aquatic plant species.

\section{Authors' contributions}

All authors in this paper have contributed equally toward the publication of this paper.

\section{Acknowledgments}

We would like to thank the members of the Marine Biology Department, Marine Sciences Center, Basrah University, for help me in accomplishing this work and for their valuable advice and suggestions.

\section{References}

Acosta BO and Pullin RSV 1991. Environmental impact of the golden apple snail (Pomacea sp.) on rice farming systems in the Philippines. Freshwater Aquaculture Center, Central Luzon State University, Munoz, Nueva Ecija; ICLARM, Manila, vi +34 pp .

Baker P, Zimmanck F, Baker SM . 2010. Feeding rates of an introduced freshwater gastropod Pomacea insularum on native and nonindigenous Aquatic plants in Florida. J Mollus Stud 76:138-143 
Borges, N.; PITELLI, R. A. (2004). Adjuvantes e herbicidas e a infectividade de Fusarium graminearum, agente potencial de biocontrole de Egeria densa e Egeria najas. Planta Daninha, v. 22, n. 1, p. 77-83.

Carlsson NOL, Brönmark C. 2006. Size-dependent effects of an invasive herbivorous snail (Pomacea canaliculata) on macrophytes and periphyton in Asian wetlands. Freshw Biol 51,4:695-704

Carlsson NOL, Lacoursie're JO. 2005. Herbivory on aquatic vascular plants by the introduced golden apple snail (Pomacea canaliculata) in Lao, PDR. Biol Invasions 7:233-241.

Center, T. D., Parys, K., Grodowitz, M., Wheeler, G. S., Dray, F. A., O'Brien, C. W., Johnson, S., Cofrancesco, A., 2013. Evidence of establishment of Bagous hydrillae (Coleoptera: Curculionidae), a biological control agent of Hydrilla verticillata (Hydrocharitales: Hydrocharitaceae) in North America. Florida Entomol., v. 96, n. 1, p. 180-186. http://www.fcla.edu/FlaEnt/ doi: 10.1653/024.096.0124.

Estebenet, A. L. 1995. Food and feeding in Pomacea canaliculata (Gastropoda: Ampullariidae). The Veliger, v. 38, n. 4, p. 277-283.

Estebenet, A. L.; Martin, P. R. Shell. 1988. interpopulation variation and its origin in Pomacea canaliculata (Gastropoda: Ampullaridae) from southern pampas, Argentina. J. Mollus. Stud., v. 69, n. 4, p. 301-310, 2003.

Estebenet, AL. and Cazzaniga, NJ.,, 1993. Egg variability and the reproductive strategy of Pomacea canaliculata (Gastropoda: Ampullariidae). Apex, 8: 129-138.

Gettys, L. A. , Haller, W.T. and Petty, D.G. 2009. editors. Biology and control of aquatic plant: A best management practices handbook. Aquatic Ecosystem Restoration Foundation, 210 p.

Halwart, M. The golden apple snail Pomacea canaliculata in Asian rice farming systems: present impact and future threat. Inter. J. Pest Manag., v. 40, n. 1, p. 199-206,1994.

HIRAI, Y. Apple snail in Japan: the present status and management. JARQ Japan, v. 22, n. 1, p. 161-165.

LACH, L. et al.2000. Food preference and reproductive plasticity in an invasive freshwater snail. Biol. Invas., v. 2, n. 4, p. 279-288.

Miyazaki, D. M. Y.; Pitelli, R. A. 2003. Estudo do potencial do pacu (Piaractus mesopotamicus) como agente de controle biológico de Egeria densa, E. najas e Ceratophyllum demersum. Planta Daninha, v. 21, p. 53-59.

Naylor R 1996. Invasions in agriculture: assessing the cost of the golden apple snail in Asia. Ambio 25: 443448 .

Newman, R. M. 2004. Invited review: Biological control of Eurasian watermilfoil by aquatic insects: basic insights from an applied problem. Archiv Fuer Hydrobiol., v. 159, n. 2, p. 145-184.

Qio, J. W. Chan, M. T. Kwog, K. L. AND Sun, J. 2011. Consumption, survival and growth in the invasive reshwater snail Pomacea canaliculata: does food freshness matter? J. Mollus. Stud., v. 77, n. 2, p. 189-195.

Qiu, J. W.; Kwong, K. L. 2009. Effects of macrophytes on feeding and life-history traits of the invasive apple snail Pomacea canaliculata. Freshwater Biol., v. 54, n. 8, p. 1720-1730.

Silva, A. F. et al.2014. Utilização da carpa capim (Ctenopharyngodon idella) como agente de controle biológico de macrófitas aquáticas submersas. Planta Daninha, v. 32, n. 4, p. 765-773.

Simone, L.R.L., 2006. Land and freshwater mollusks of Brazil. São Paulo: EGB; Fapesp. 390 p.

Sousa, W. T. Z. 2011. Hydrilla verticillata (Hydrocaritaceae), a recent invader threatening Brazil's freshwater environments: a review of the extent of the problem. Hidrobiologia, v. 669, n. 1, p. 1-20.

Wong, P.K., Liang, Y., Liu, N.Y. \& Qiu, J.W. 2010. Palatability of macrophytes to the invasive freshwater snail Pomacea canaliculata: differential effects of multiple plant traits. Freshwater Biology, 55: 2023- 2031. 